Philippine Pagans

The Autobiographies of Three Ifugaos. By R. F. Barton. Pp. xxi $+271+24$ plates. (London : George Routledge and Sons, Ltd., 1938.) 158. net.

THE three Ifugao autobiographies comprised in this volume were collected in the course of an ethnographical investigation, which lasted for the greater part of 1937, in the island of Luzon. They attain a new standard in the attempt to eliminato the point of view of the white observer in cultural investigation. The subjects, two men and a woman, were told to record matters which they considered of most interest and importance in their lives. The narrative was, of course, taken down by the author, as the narrators were both pagan and illiterate. The result is significant in every sense. The topic which bulks largest is the pre-marital sexual relation, although for the woman, its special interest was its bearing on marriage and child-birth; but the influence of omens and the social ties of kinship and propinquity are also prominent in their influence on the course of events. Head-hunting figures repeatedly but it seems to be treated as of incidental, rather than of primary importance.

The institution which is pivotal in these norratives is that of the custom of the unmarried of both sexes sleeping in dormitories, either empty or occupied houses, apart from their families, and the consequent visiting of the females by the males, adolescent and mature. It is interesting to note that the author, as a result of the employment of this method of investigation and the intimate insight it has afforded him into native mentality, has had to reconsider an interpretation of the pre-marital sexual relation which he had based upon his experience of native institutions acquired in a residence among them over a period of seven years.

\section{Archrology and Society}

By Grahame Clark. Pp. xv $+220+24$ plates. (London: Yethuen and Co., Ltd., 1939.) 7s. 6d. net.

RCH $Æ O L O G Y$, no less than other branches of research, has profited from the increased popular interest in the results of scientific inquiry and their application to social ends which followed on the close of the War of 1914-18. If the practical bearing of archæological aims was less immediately apparent, this was counterbalanced by a number of spectacular discoveries, of which it will suffice to recall that of King Tutankhamen's tomb in Egypt and Sir Leonard Woolley's excavations at Ur. While it is beyond question that the study of archæology has profited much and gathered strength from this enhancement of popular interest, the constant stimulus of sensation needed to keep it alive has obvious dangers which may affect the quality of the investigation.

The present excellent review of the aims and methods of modern archæological investigation is de. signed to supply the public outside the ranks of the specialist with the basis of knowledge requisite to enable them to appreciate the bearing of archæological results achioved in the field, as well as the technical skill and the acumen in interpretation which contribute to the result. Thus in successive chapters he deals with discovery, in which it is explained how the archrologist knows where to dig, the preservation of early remains, depending upon the survival value of different materials, the methods and aims of the actual excavation, chronology, based upon stratigraphy and sequence, and interpretation, in that last tracing how the interest of modern archæological investigation no longer centres on the discovery of exceptional examples of the artistic products of the past, but in the reconstruction of the essential elements in the day-to-day life of the peoples of vanished civilizations.

In his final chapter on "Archæology and Socioty" Dr. Clark discusses certain aspects of archæological studiez as a factor in modern life, and roviews briefly its relation to the development of nationalist sentiment in the smaller States which came into being after the War of 1914-18, as well as in Russia, Italy, Germany and Eiro. While his readers will concur in his praise for what is being done in Eire, they will find his account of archæological activities in Russia, in which he relies on the evidence of Prof. A. Mr. Tallgren, more than disturbing, and probably feel that his view of the tendentious character of German theory under the Nazi regime is all too lenient.

\section{BIOLOGY}

\section{British Purbeck Charophyta}

By Prof. Thomas Maxwell Harris. Pp. ix $+83+17$ plates. (London: British Aruseum (Natural History), 1939.) $7 s .6 d$.

THE Charophyta have usually been regarded as a somewhat isolated group of Thallophyta, but the author of this monograph probably rightly regards them as a family of the Chlorophycex. Like some members of the Rhodophycex and Siphonales, they have left as records of their existence in past ages the calcareous clothing with which they invested their thallus. With the exception of the oospore membrane all the original plant substance has disappeared.

There are two important families in the group, the Characex and the Clavatoracex. By careful analysis of large numbers of fragmentary specimens which were extracted from the rock, the author has boen able to distinguish some new and interesting types. A new genus, Charaxis, has been instituted for vegetative organs of fossil Charophyta, and one new species, $C$. durlstonense, is described. The most interesting and important part of the monograph consists of very complete descriptions of threo species of the genus Clavator; $C$. reidi Groves, and two new species $C$. grovesi and $C$. bradleyi. A new genus, Perimneste, with one species, $P$. horrida, is of exceptional interest. These forms are all included in the Clavatoracex. There are careful detailed analyses of the construction of the thallus and the oogonia, and the descriptions are fully illustrated with photographs of a high order of excellence. Clear diagram- 